\title{
The Effects of Gender and Gonadal Steroids on the Neuroendocrine and Temperature Response to m-Chlorophenylpiperazine in Leuprolide-induced Hypogonadism in Women and Men
}

Peter J. Schmidt, M.D., Jamuna Raju, M.D., Merry Danaceau, R.N., M.S.N., Dennis L. Murphy, M.D., and Robin E. Berlin, B.S.

Studies of the effects of gender and gonadal steroids on serotonergic activity in humans are few in number and often contradictory. We examined the neuroendocrine and core temperature response to a serotonergic stimulus, $\mathrm{m}$-chlorophenylpiperazine ( $\mathrm{m}$-CPP) $(0.08 \mathrm{mg} / \mathrm{kg}$ body weight, $I V)$, in asymptomatic female and male volunteers during induced hypogonadism (leuprolide acetate) and hormone replacement (estradiol (E2) or progesterone (P4) in women; testosterone (T) in men).

Compared with the hypogonadal state, basal prolactin $(P R L)$ secretion was significantly higher during both P4 and $E 2$ replacement $(\mathrm{p}<.05)$ in women and during $T$ replacement in men $(\mathrm{p}<.05)$. m-CPP stimulated PRL secretion was significantly greater only during $P 4(\mathrm{p}<$ .05) but not E2 (women) or $T$ (men) replacement, compared with hypogonadism. Basal but not stimulated plasma growth hormone (GH) levels were significantly higher during $P 4$ in women and $T$ in men $(\mathrm{p}<.05)$, and no significant differences in basal or m-CPP stimulated plasma levels of ACTH or cortisol were observed. Finally, basal core temperatures were significantly higher during P4 replacement compared with either E2 replacement or the hypogonadal condition $(\mathrm{p}<.01)$ in women, with no differences observed in men. Comparisons of measures by gender (and matched for baseline plasma T levels) revealed that during the hypogonadal state $m-C P P$-stimulated $G H$ secretion was significantly greater $(\mathrm{p}<.01)$ and $m-C P P-$ stimulated ACTH $(\mathrm{p}<.05)$ and cortisol $(\mathrm{p}<.01)$ significantly less in women compared with men.

Although our data are limited to those components of the central serotonergic system influenced by $m-C P P$ administration, our findings suggest the following: the regulatory effects of gonadal steroids on serotonergic function are modest in humans during leuprolide-induced hypogonadism; menstrual cycle phase effects of serotonergic agents on PRL secretion may reflect both the effects of P4 and E2; the effects of P4 in humans may occur without E2 priming of the progesterone receptor; and gender differences in GH secretion occur independent of the presence of gonadal steroids.

[Neuropsychopharmacology 27:800-812, 2002]

(C) 2002 American College of Neuropsychopharmacology.

Published by Elsevier Science Inc.

From the Behavioral Endocrinology Branch (PJS, JR, REB), Clinical Center Nursing Department (MD), and Laboratory of Clinical Science (DLM), National Institute of Mental Health, Bethesda, Maryland 20892-1276.

Address correspondence to: Peter J. Schmidt, M.D., NIMH, Bldg. 10, Room 3N238, 10 Center Drive MSC 1276, Bethesda, MD 20892-1276. Tel.: 301-496-9675; Fax: 301-402-2588; Email: Peter.Schmidt@NIH.GOV

Online publication: 3/20/02 at www.acnp.org/citations/Npp032002271.

Received June 29, 2001; revised March 12, 2002; accepted March 15, 2002. 
KEY WORDS: Estradiol; Progesterone; Testosterone; Serotonin; Prolactin; Humans

A wide range of convergent data suggest that both gender and the gonadal steroids, estradiol (E2), progesterone (P4), and testosterone (T), modulate serotonergic system function. These interactions of gender and gonadal steroids with the central serotonergic system are of clinical importance: (1) serotonin modulatory agents are effective treatments for mood disorders linked to changes in reproductive endocrine function (Lepage and Steiner 1991); (2) sexual dimorphisms exist in the relative efficacy of serotonergic compared with tricyclic antidepressants (Kornstein et al. 2000); and (3) the efficacy of serotonergic agents may be enhanced by estradiol in depressed peri and postmenopausal women (Schneider et al. 1997; N. Rasgon et al., personal communication). In rodents, brain region-specific concentrations of serotonin, serotonin receptor subtypes, and responses to serotonin agonists vary with gender, with estrus cycle phase, and after castration with or without hormone replacement (Fink et al. 1996; Rubinow et al. 1998; Fischette et al. 1984). In humans, gender differences have been reported in whole brain serotonin synthesis (Nishizawa et al. 1997), 5-HT2 receptor binding capacity (Biver et al. 1996), and the responses to tryptophan depletion (Ellenbogen et al. 1996; Anderson et al. 1990), d-fenfluramine (Goodwin et al. 1994), and m-chlorophenylpiperazine (m-CPP) (Murphy et al. 1989; Su et al. 1997; Charney et al. 1987). Additionally, putative markers of serotonergic system function (e.g., platelet imipramine binding sites (Sherwin and Suranyi-Cadotte 1990), platelet serotonin content (Guicheney et al. 1988), and urinary levels of 5-hydroxyindole acetic acid (Lippert et al. 1996)) have been reported to change during postmenopausal estrogen replacement, and serotonin agoniststimulated neuroendocrine secretion has been reported to change both across the menstrual cycle and after hormone replacement (Su et al. 1997; Yatham et al. 1989; O'Keane et al. 1991; Halbreich et al. 1995). Most of the observed sexual dimorphisms and menstrual cycle phase-related changes in CNS function in humans are presumed to reflect alterations in estrogen secretion, while the potential regulatory effects of progesterone have been either ignored or viewed solely as modifications of the effects of estrogen.

One of several strategies employed in humans to investigate the effects of gonadal steroids on central serotonin function is the administration of relatively nonspecific serotonin agonists to assess the "sensitivity" (i.e. the extent) of serotonergically mediated events. One such agonist, $\mathrm{m}-\mathrm{CPP}$, has been employed extensively, with studies demonstrating that a variety of physiologic responses to $\mathrm{m}-\mathrm{CPP}$ vary in the context of postmenopausal estrogen replacement (Halbreich et al.
1995), across menstrual cycle phases (Su et al. 1997), and across genders (Murphy et al. 1989; Charney et al. 1987). Since both T and E2/P4 may modulate serotonergic activity, it is difficult under normal conditions to identify gender differences that are not gonadal steroiddependent. Consequently, we attempted to disentangle the effects of gonadal steroids and gender on central serotonergic function by employing $\mathrm{m}-\mathrm{CPP}$ as a pharmacologic probe during experimentally constructed hypogonadal and hormone replaced conditions in men and women. Further, by performing these studies in young men and women the effects of hypogonadism can be examined independent of the influences of aging, which may confound studies performed in climacteric men and women.

In this study, we asked the following questions: (1) Can we demonstrate modulation of the response to serotonergic stimulation by $\mathrm{E} 2$ or $\mathrm{P} 4$ in women or by $\mathrm{T}$ in men? (2) Are there gender differences in the response to serotonergic stimulation? (3) Do the gender differences exist in a gonadal steroid independent manner; i.e. are they present during induced hypogonadism? Our measures of physiologic response consisted of the elevation of plasma hormone levels and core temperature after a serotonergic stimulus, $\mathrm{m}-\mathrm{CPP}$, in women and men volunteers during separate hormonal conditions: women: GnRH agonist (depot leuprolide acetate)-induced hypogonadism, GnRH agonist-induced hypogonadism with E2 replacement, and GnRH agonist-induced hypogonadism with $\mathrm{P} 4$ replacement. Men: GnRH agonistinduced hypogonadism, GnRH-agonist-induced hypogonadism with $\mathrm{T}$ replacement.

\section{METHODS}

\section{Subject Selection}

Subjects were 11 women and 11 men (mean \pm SD age $=$ $30 \pm 7$ and $29 \pm 7$ years, respectively) recruited through advertisements in the hospital newsletter or referred from the NIH Normal Volunteer Office. All were medication free, the women reported having regular menstrual cycles ranging from 23 to 33 days in length, and all were screened for the absence of significant medical illness (current or in the past two years) through history, physical examination, and routine laboratory tests (including thyroid function tests). All subjects were administered a structured psychiatric diagnostic interview, the Structured Clinical Interview for DSM-III-R (Spitzer et al. 1990), to confirm the absence of current or past Axis I psychiatric illness. Before participating in the study, all subjects completed daily visual analog scale self-ratings for at least two months to exclude the presence of premenstrual or other mood disturbances. Pregnancy tests were performed in the women prior to the study, and all women were required to employ bar- 
rier contraceptive methods during the course of the study. The protocol was reviewed and approved by the National Institute of Mental Health Intramural Research Review Board, and oral and written informed consents were obtained from all subjects. All subjects were paid for their participation in this protocol according to the guidelines of the NIH Normal Volunteer Office.

\section{Procedure}

Hormonal Manipulation Protocol. All women received depot Lupron, (leuprolide acetate, TAP Pharmaceuticals, Chicago, IL) $3.75 \mathrm{mg}$ by intramuscular injection every four weeks for five months. Lupron alone was administered for the first eight weeks. Subjects then received, in addition to Lupron, $17 \beta$ E2 $(0.1 \mathrm{mg} /$ day) by skin patch (Estraderm, Ciba Geigy, Raritan, NJ) or P4 suppositories (200 mg b.i.d.) (NIH Pharmacy, Bethesda, MD) for five weeks each. The two "addback" regimens were separated by a 2-week washout period. Subjects were administered both patches and suppositories (active or placebo, depending upon the treatment phase) daily throughout the entire addback period to ensure the double-blind was maintained. The order of receiving estrogen and $\mathrm{P} 4$ was randomly assigned and counter-balanced. During the last week of E2 addback all subjects received one week of active $\mathrm{P} 4$ suppositories in addition to E2 to precipitate menses. All women received prepackaged one week unit-dose supplies of suppositories that were formulated and coded (weeks 1-5) by the NIH Pharmacy Department. All men received depot Lupron $7.5 \mathrm{mg}$ by intramuscular injection every four weeks for three months. Lupron alone was administered for the first four weeks. Subjects then received, in addition to Lupron, $\mathrm{T}$ enanthate $(200 \mathrm{mg})$ or placebo (sesame oil) given by intramuscular injection every two weeks for one month. All men received one month each of $\mathrm{T}$ and placebo, the order of which was randomly assigned and counter-balanced.

All subjects were invited to undergo m-CPP challenge tests as follows: Women: after six weeks of Lupron alone (hypogonadal) and after at least two weeks of hormone replacement (Lupron plus E2 and Lupron plus P4). Men: after at least two weeks of T replacement and after at least two weeks of placebo replacement (hypogonadal). The season (e.g. winter versus summer) during which m-CPP tests were performed was not randomly assigned or counter-balanced.

m-CPP Challenge. The procedure for the m-CPP test (detailed elsewhere) (Murphy et al. 1989), consisted of an open label intravenous (IV) administration of m-CPP at a dose of $0.08 \mathrm{mg} / \mathrm{kg}$ body weight at approximately $0915 \mathrm{~h}$ (0 min), $45 \mathrm{~min}$ after IV catheter placement. All subjects had fasted since midnight prior to the procedure. Blood samples were obtained at baseline $(-10$ and $0 \mathrm{~min}$ ) and during the next $90 \mathrm{~min}$ (at +3 and +6 min for m-CPP levels only, and at 10 min intervals for one hour and at $90 \mathrm{~min}$ for hormonal measures and $\mathrm{m}$ CPP levels). Core body temperature was measured by a rectal temperature probe (Steri-probe, Cincinnati Subzero Products Inc., Cincinnati, $\mathrm{OH}$ ) and then recorded on a physiologic monitor (Science Electronics Inc., Miamisburg, $\mathrm{OH}$ ) at baseline and subsequently every ten minutes for $90 \mathrm{~min}$.

\section{Hormonal Measures}

Blood samples were collected for the measurement of plasma levels of cortisol, prolactin (PRL), adrenocorticotropic hormone $(\mathrm{ACTH})$, growth hormone $(\mathrm{GH})$, and $\mathrm{m}$-CPP. The hormones measured were those previously shown to be stimulated by m-CPP (Murphy et al. 1989, 1995; Anand et al. 1994) and, therefore, serve as potential outcome measures of m-CPP's activity on the serotonergic system. Plasma was stored at $-70^{\circ} \mathrm{C}$ until time of analysis. With the exception of total and free $\mathrm{T}$ plasma hormone assays were performed at Hazelton Laboratories (Vienna, VA) by methods previously described (cortisol (Klemm and Gupta 1975), ACTH (Chrousos et al. 1984), GH (Odell et al. 1967), PRL (Aubert et al. 1974)). The intra- and interassay coefficients of variation were $3.8 \%$ and $9.9 \%$ for cortisol, $8.5 \%$ and $13.3 \%$ for ACTH, $2.1 \%$ and $11.3 \%$ for GH, $4.6 \%$ and $13.0 \%$ for PRL. Baseline plasma levels of E2 and P4 were analyzed by radioimmunoassay (Abraham et al. 1971; Jiang and Ryan 1969). Total (Furuyama et al. 1970) and free T (by equilibrium dialysis) (Vermeulen et al. 1971) were assayed at Quest Diagnostics (Baltimore, MD). Plasma m-CPP levels were measured as described previously (Murphy et al. 1989).

\section{Statistical Analysis}

In women, plasma hormone and m-CPP levels as well as temperature records at each time point were compared by analysis of variance with repeated measures (ANOVA-R; Systat, SPSS, Chicago, IL), with hormone condition (hypogonadal vs. E2 replacement vs. P4 replacement) and time as the within-subjects variables. Additionally, measures of plasma hormone secretion, including baseline levels, integrated area under the secretory curve (AUC; calculated by the trapezoidal integration method), and the difference between baseline and maximum stimulated levels ( $\Delta$ max) were compared by ANOVA-R with hormone condition as the within-subjects variable. Baseline and $\Delta$ max temperature records were analyzed in an identical manner. In men, outcome measures were compared in a separate analysis from the women with hormone condition (hypogonadal vs. T replacement) and time as the within-subjects variables. Finally, during the hypogonadal $\mathrm{m}-\mathrm{CPP}$ testing 
only, gender differences in plasma hormone and m-CPP levels and temperature records were compared by ANOVA-R with gender as the between-subjects variable and time (when appropriate) as the within-subjects variable. When justified by a significant hormone condition $\times$ time or a gender $\times$ time interaction effect (or a significant effect of hormone condition alone for baseline, AUC, $\Delta$ max), post hoc Bonferroni $t$-tests were performed. Due to variability in plasma $\mathrm{T}$ levels between the men and women during Lupron-induced hypogonadism, these analyses were repeated in a subgroup of five men and five women matched for baseline plasma $\mathrm{T}$ levels (within $1 \mathrm{ng} / \mathrm{dl}$ ). Thus statistical comparisons by gender during the hypogonadal state will be reported for the entire sample as well as the matched subgroup. Values are reported in the text and tables as the mean \pm SD.

When indicated by a significant effect of hormone condition after ANOVA-R, a secondary analysis was performed by ANOVA-R with order of hormone addback (ie. E2 or P4 first) as the between-subjects variable. Additionally, Student's $t$-test was employed to examine differences in $\Delta$ max and AUC PRL between women receiving P4 first and those first receiving E2 replacement.

\section{RESULTS}

\section{Basal Plasma Gonadal Steroid Levels}

In women during the hypogonadal, E2 replaced, and P4 replaced conditions, plasma levels of E2 ( $\mathrm{pmol} / \mathrm{L})$ and P4 (nmol/L) were as follows: $54.3 \pm 18.4,1.3 \pm 0.3$; $360.4 \pm 97.3,1.6 \pm 0.3$; and $55.4 \pm 14.7,49.3 \pm 17.3$, respectively (Table 1 ). In women during hypogonadism, plasma T levels $(\mathrm{nmol} / \mathrm{L})$ were $0.6 \pm 0.2$. In men during the hypogonadal and $\mathrm{T}$ replaced conditions, plasma $\mathrm{T}$ levels $(\mathrm{nmol} / \mathrm{L})$ and free T levels $(\mathrm{pmol} / \mathrm{L})$ were $1.6 \pm$ $1.1,8.3 \pm 6.6$; and $18.2 \pm 9.9,109.3 \pm 55.9$, respectively. In the matched sample of men and women during the hypogonadal condition, plasma T levels $(\mathrm{nmol} / \mathrm{L})$ were $0.7 \pm 0.3$ and $0.7 \pm 0.4$, respectively.

\section{Effects of Gonadal Steroids}

Plasma m-CPP Levels. Plasma m-CPP levels after injection were significantly higher during E2 replacement conditions compared with the hypogonadal state (at +3 and $+6 \mathrm{~min}$ ) and compared with $\mathrm{P} 4$ replacement (at +6 min only); comparisons at other time points were not significantly different (Figure 1). Plasma concentrations of $\mathrm{m}-\mathrm{CPP}$ could not be measured during E2 replacement in one woman and P4 replacement in another, due to insufficient sample volume. Similarly, plasma $\mathrm{m}$-CPP levels after injection were significantly higher during $\mathrm{T}$ replacement compared with the hypogonadal state at +3 and $+6 \mathrm{~min}$, but comparisons at other time points were not significantly different.

The mean doses of $\mathrm{m}$-CPP during each hormone condition were not significantly different and were as follows: Women: hypogonadal condition $4.9 \pm 0.8 \mathrm{mg}$, E2 replacement $5.0 \pm 0.8 \mathrm{mg}$, and $\mathrm{P} 4$ replacement $4.9 \pm$ $0.8 \mathrm{mg}$; Men: hypogonadal condition $6.5 \pm 0.7 \mathrm{mg}$, and $\mathrm{T}$ replacement $6.6 \pm 0.7 \mathrm{mg}$.

Prolactin. In women, post hoc testing showed that basal PRL secretion was significantly higher during both P4 and E2 replacement compared with the hypogonadal state $\left(\mathrm{t}_{20}=2.8\right.$ and 3.0, respectively; $\left.p<.05\right)$ (Table 2). During P4 (but not E2) replacement, m-CPP stimulated plasma PRL levels were significantly greater than those during the hypogonadal state at 50,60, and $90 \mathrm{~min}$ post $\mathrm{m}-\mathrm{CPP}$ administration $(p<.05)$ (Figure 2$)$; the AUC PRL and $\Delta$ max of the plasma PRL levels were also significantly increased during P4 replacement $\left(t_{20}=2.8\right.$ and 2.5,

Table 1. Basal plasma gonadal steroid levels in women and men during Lupron-induced hypogonadism and gonadal steroid replacement (mean \pm SD).

\begin{tabular}{lccc}
\hline & Hypogonadal & E2 Replaced & P4 Replaced \\
\hline Women (n = 11) & & & \\
E2 pmol/L & $54.3 \pm 18.4$ & $360.4 \pm 97.3$ & $55.4 \pm 9.9$ \\
$\mathrm{P} 4 \mathrm{nmol} / \mathrm{L}$ & $1.3 \pm 0.3$ & $1.6 \pm 0.3$ & $49.3 \pm 17.3$ \\
T nmol/L & $0.6 \pm 0.2$ & $0.7 \pm 0.2$ & \\
& & & \\
& Hypogonadal & T Replaced & \\
Men $(\mathrm{n}=11)$ & $1.6 \pm 1.1$ & $18.2 \pm 9.9$ & \\
T nmol/L & $8.3 \pm 6.6$ & $109.3 \pm 55.9$ & \\
FT pmol/L & $23.4 \pm 6.6$ & $93.9 \pm 38.75$ & \\
E2 pmol/L & $55.9 \pm 33.3$ & $146.5 \pm 41.0$ & \\
E1 pmol/L & &
\end{tabular}

Conversions: $\mathrm{E} 2$ and $\mathrm{E} 1$ from $\mathrm{pmol} / \mathrm{L}$ to $\mathrm{pg} / \mathrm{ml}$ - multiply by .272 and .270 , respectively. T from $\mathrm{nmol} / \mathrm{L}$ to ng/dL - multiply by 28.8

$\mathrm{P} 4$ from $\mathrm{nmol} / \mathrm{L}$ to $\mathrm{ng} / \mathrm{ml}$ - multiply by .315 .

$\mathrm{E} 2=$ estradiol, $\mathrm{P} 4=$ progesterone, $\mathrm{T}=$ testosterone, $\mathrm{FT}=$ free testosterone, $\mathrm{E} 1=$ estrone. 

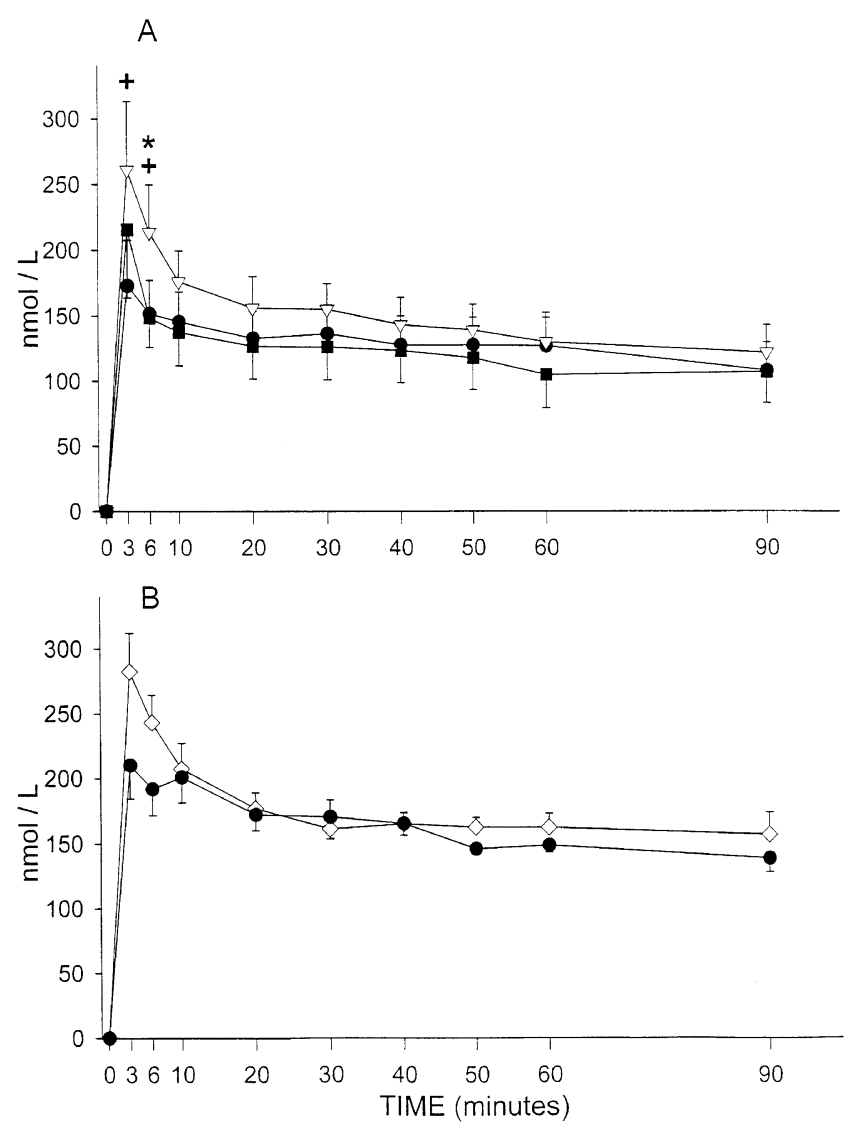

Figure 1. Mean \pm SEM plasma m-CPP levels across different hormonal conditions. A. Women: Plasma m-CPP levels were significantly higher during the E2 replacement condition compared with the hypogonadal state at +3 and +6 min (ANOVA-R: hormone condition $\times$ time interaction: $\mathrm{F}_{16,128}=2.2, p=.01 ; \mathrm{t}_{144}=4.7,3.3$, respectively; $\left.p<.05\right)$ and compared with $\mathrm{P} 4$ replacement at +6 min only $\left(\mathrm{t}_{144}=3.5\right.$, $p<.05)$. No significant differences in m-CPP levels were present after ten minutes and subsequently throughout the duration of the study. ( hypogonadal; $\nabla$ E2 replaced; $\mathbf{D} 4$ replaced) $\left({ }^{+} \mathrm{E} 2\right.$ replacement vs. hypogonadal state: $p<.05$; * E2 replacement vs. P4 replacement: $p<.05)$. B. Men: Plasma m-CPP levels were significantly higher during $\mathrm{T}$ replacement compared with the hypogonadal state at +3 and +6 min (ANOVA-R: hormone condition $\times$ time interaction: $\mathrm{F}_{8,80}=4.5, p<.001 ; \mathrm{t}_{90}=4.5,3.2$, respectively, $\left.p<.05\right)$. No significant differences in $\mathrm{m}-\mathrm{CPP}$ levels were present after ten minutes and subsequently throughout the duration of the study. ( hypogonadal; $\diamond \mathrm{T}$ replaced)

respectively; $p<.05)$. Stimulated PRL secretion was significantly greater during $\mathrm{P} 4$ compared with E2 replacement conditions at $90 \mathrm{~min}\left(\mathrm{t}_{160}=3.4, p<.05\right)$ as were the AUC PRL and $\Delta$ max of PRL secretion $\left(t_{20}=3.5\right.$ and 2.6, respectively; $p<.05)$. No significant interaction between order of hormone administration and PRL response was identified. However, non-significant differences in $\mathrm{m}$-CPP stimulated PRL secretion were observed between those women $(n=5)$ receiving P4 first (not estrogen primed)
$(\Delta$ max PRL: $16.1 \pm 9.7 \mu \mathrm{g} / \mathrm{L}$; AUC PRL: $868.3 \pm 614)$ and those receiving $\mathrm{P} 4$ after the E2 addback $(\mathrm{n}=6)(\Delta \max$ PRL: $6.8 \pm 2.2 \mu \mathrm{g} / \mathrm{L}$; AUC PRL: $355.2 \pm 188$ ) (Student's $t$-test: $\Delta$ max, $p=.07$; AUC, $p=.1$ ).

In men, ANOVA-R showed that basal PRL secretion was significantly higher during $T$ replacement compared with the hypogonadal state (Table 3). m-CPP-stimulated PRL secretion during $T$ replacement remained significantly elevated throughout the test compared with the hypogonadal state (Figure 2); however, baseline corrected measures (i.e., $\Delta$ max and AUC PRL) were not significantly different between $\mathrm{T}$ replaced and hypogonadal states (Table 3, Figure 2).

Growth Hormone. In women, compared with the hypogonadal state, basal plasma GH levels were significantly higher during P4 replacement and higher, but not significantly so, during E2 replacement (Table 2). ANOVA-R showed a significant hormone condition $\times$ time interaction effect for plasma GH levels, which appeared to reflect both lower basal GH levels during the hypogonadal state and a more precipitous rise during E2 replacement. However, m-CPP stimulated GH measures showed considerable variance, and no significant differences during the three hormonal conditions were observed for the AUC or $\Delta$ max of GH secretion.

In men, ANOVA-R showed that plasma GH secretion was significantly higher (at all time points combined) during $\mathrm{T}$ replacement compared with the hypogonadal condition $\left(\mathrm{F}_{1,10}=6.3, p<.05\right)$ (Figure 2). Basal GH levels were higher but not significantly so during $\mathrm{T}$ replacement compared with the hypogonadal conditions. The AUC and $\Delta$ max of GH secretion showed that m-CPP did not result in a significant increase in GH secretion in men (in contrast to that observed in women) (Table 3). Furthermore, the lack of $\mathrm{m}-\mathrm{CPP}$-stimulated $\mathrm{GH}$ secretion in men suggests that the significantly increased plasma GH levels on T replacement identified by the ANOVA-R reflected a general elevation of $\mathrm{GH}$ secretion during $\mathrm{T}$ replacement rather than any specific effect of m-CPP stimulation on $\mathrm{GH}$ secretion.

ACTH and Cortisol. Compared with both the hypogonadal and E2 replaced conditions in women, basal plasma cortisol levels were higher, albeit at a trend level of significance, during P4 replacement. No differences were observed in basal plasma ACTH levels or in $\mathrm{m}-\mathrm{CPP}-$ stimulated levels of cortisol and ACTH secretion across the three hormonal conditions. m-CPPstimulated ACTH was non-significantly greater during P4 replacement largely due to one subject's substantially increased levels of stimulated ACTH (Table 2, Figure 3). Similarly, in men, no significant differences were observed in basal or m-CPP-stimulated plasma 
Table 2. Basal and m-CPP Stimulated Plasma Hormone Levels in Women during Lupron-induced Hypogonadism and after E2 and P4 Replacement. (mean \pm SD)

\begin{tabular}{|c|c|c|c|c|}
\hline & Lupron alone & Lupron and E2 & Lupron and $\mathrm{P} 4$ & ANOVA-R $\mathrm{F}_{2,20}(p)$ \\
\hline \multicolumn{5}{|c|}{ PRL $(\mu \mathrm{g} / \mathrm{L})$ : } \\
\hline Basal & $6.7(1.6)$ & $9.2(3.1)^{\#}$ & $9.0(3.7)^{\#}$ & $5.9(.01)$ \\
\hline$\Delta \max$ & $6.7(3.2)$ & $6.5(4.0)$ & $11.9(8.5)^{\#, *}$ & $4.3(.03)$ \\
\hline AUC & $359.3(201.6)$ & $287.3(253.4)$ & $635.1(523.9)^{\#, *}$ & $3.6(.05)$ \\
\hline \multicolumn{5}{|c|}{ Growth Hormone $(\mu \mathrm{g} / \mathrm{L})$ : } \\
\hline Basal & $0.4(0.6)$ & $1.3(1.7)$ & $2.4(3.4)^{\#}$ & $3.1(.07)$ \\
\hline$\Delta \max$ & $4.3(3.3)$ & $6.7(8.5)$ & $5.5(6.6)$ & 0.9 (NS) \\
\hline AUC & $131.2(159.3)$ & $230.6(470.4)$ & $115.1(481.3)$ & 0.7 (NS) \\
\hline \multicolumn{5}{|c|}{ ACTH (pmol/L): } \\
\hline Basal & $2.6(1.6)$ & $2.9(1.6)$ & $3.0(2.5)$ & 0.4 (NS) \\
\hline$\Delta \max$ & $4.1(2.8)$ & $4.3(3.4)$ & $6.3(11.8)$ & 0.7 (NS) \\
\hline AUC & $161.8(127.3)$ & $213.9(182.1)$ & $313.2(605.9)$ & $0.6(\mathrm{NS})$ \\
\hline \multicolumn{5}{|c|}{ Cortisol (nmol/L): } \\
\hline Basal & $242.8(99.3)$ & $231.8(102.1)$ & $303.5(132.4)$ & $3.2(.07)$ \\
\hline$\Delta \max$ & $245.6(154.5)$ & $242.8(113.1)$ & $215.2(124.2)$ & 0.5 (NS) \\
\hline AUC & $10611.1(8635.7)$ & 9228.9 (10798.7) & $7601.1(9027.5)$ & 0.9 (NS) \\
\hline
\end{tabular}

Bonferroni $t$-tests: Compared to Lupron alone ${ }^{*} p<.05$, Compared to Lupron and E2 - $p<.05$

ACTH or cortisol levels across the two hormonal conditions (Table 3, Figure 3).

Core Temperature. Core temperature in one woman was not recorded during the $\mathrm{P} 4$ replacement condition due to mechanical failure of the physiologic monitor. In women (Figure 4, panel A), basal and m-CPP stimulated core temperature measures were significantly higher during P4 replacement compared with either E2 replacement or the hypogonadal condition. The $\Delta \max$ $\mathrm{m}$-CPP-stimulated temperature was significantly smaller during P4 replacement compared with either E2 replacement $\left(\mathrm{t}_{18}=3.2 ; p<.05\right)$ or the hypogonadal state $\left(\mathrm{t}_{18}=\right.$ 2.6; $p<.05)$, reflecting the elevated baseline temperature during P4 replacement. In men (Figure 4, panel B), no significant differences in basal or m-CPP-stimulated core temperature measures were observed during $\mathrm{T}$ replacement compared with the hypogonadal conditions.

\section{Effects of Gender during Hypogonadism}

Data are summarized in Table 1 and Table 4.

Prolactin. ANOVA-R identified a significant gender $\times$ time interaction effect $\left(\mathrm{F}_{7,140}=2.9, p<.01\right)$ reflecting a significantly lower level of PRL secretion at $90 \mathrm{~min}$ after m-CPP stimulation in the men compared with the women $\left(\mathrm{t}_{160}=2.6, p<.05\right)$. However, there were no significant differences across genders in baseline, $\Delta$ max, or AUC PRL secretion. Similar findings were observed in the group of men and women matched for baseline plasma T levels.

Growth Hormone. m-CPP-stimulated GH secretion was significantly greater during the hypogonadal conditions in women compared with men (AUC GH: $F_{1,20}=$
8.3, $p<.01 ; \Delta$ max: $\left.\mathrm{F}_{1,20}=13.8, p=.001\right)$ reflecting both an increase in the growth hormone secretion during the latter part of the $\mathrm{m}-\mathrm{CPP}$ challenge in women and the failure of $\mathrm{m}-\mathrm{CPP}$ to consistently increase $\mathrm{GH}$ secretion in men. Similar findings were observed in the subgroup of men and women matched for baseline plasma T levels.

ACTH and Cortisol. ANOVA-R showed a significant effect of gender $\left(\mathrm{F}_{1,20}=4.6, p<.05\right)$ and a significant gender $\times$ time interaction $\left(\mathrm{F}_{7,140}=2.3, p<.05\right)$ for ACTH, reflecting higher plasma ACTH levels throughout the challenge (at all time points combined) in men compared with the women. Basal ACTH levels were higher in the men, albeit at a trend level of significance; m-CPP-stimulated plasma ACTH levels $(\Delta$ max or AUC ACTH) did not significantly differ in men and women despite higher increases in men (Table 4). A similar pattern of gender-related differences was observed in plasma cortisol secretion, with ANOVA-R identifying a significant effect of gender $\left(\mathrm{F}_{1,20}=11.7, p<\right.$ .01 ), reflecting significantly higher levels at baseline and at all time points through the $\mathrm{m}-\mathrm{CPP}$ challenge in the men compared with the women. Basal cortisol levels again were higher in the men at a trend level of significance (Table 4) without significant gender differences in the AUC or $\Delta$ max cortisol secretion. Results of a reanalysis of ACTH and cortisol secretion in men and women during the hypogonadal condition and matched for baseline plasma $T$ levels showed more robust differences in stimulated but not basal levels: compared with the women, men had significantly greater $\Delta$ max and AUC of both ACTH and cortisol secretion $\left(\mathrm{F}_{1,8}=6.2-7.4\right.$, $p=.03-.04$ for ACTH; $\mathrm{F}_{1,8}=5.3-9.4, p=.02-.045$ for cortisol). However, in this smaller matched sample we observed no significant gender differences in baseline plasma ACTH or cortisol levels. 

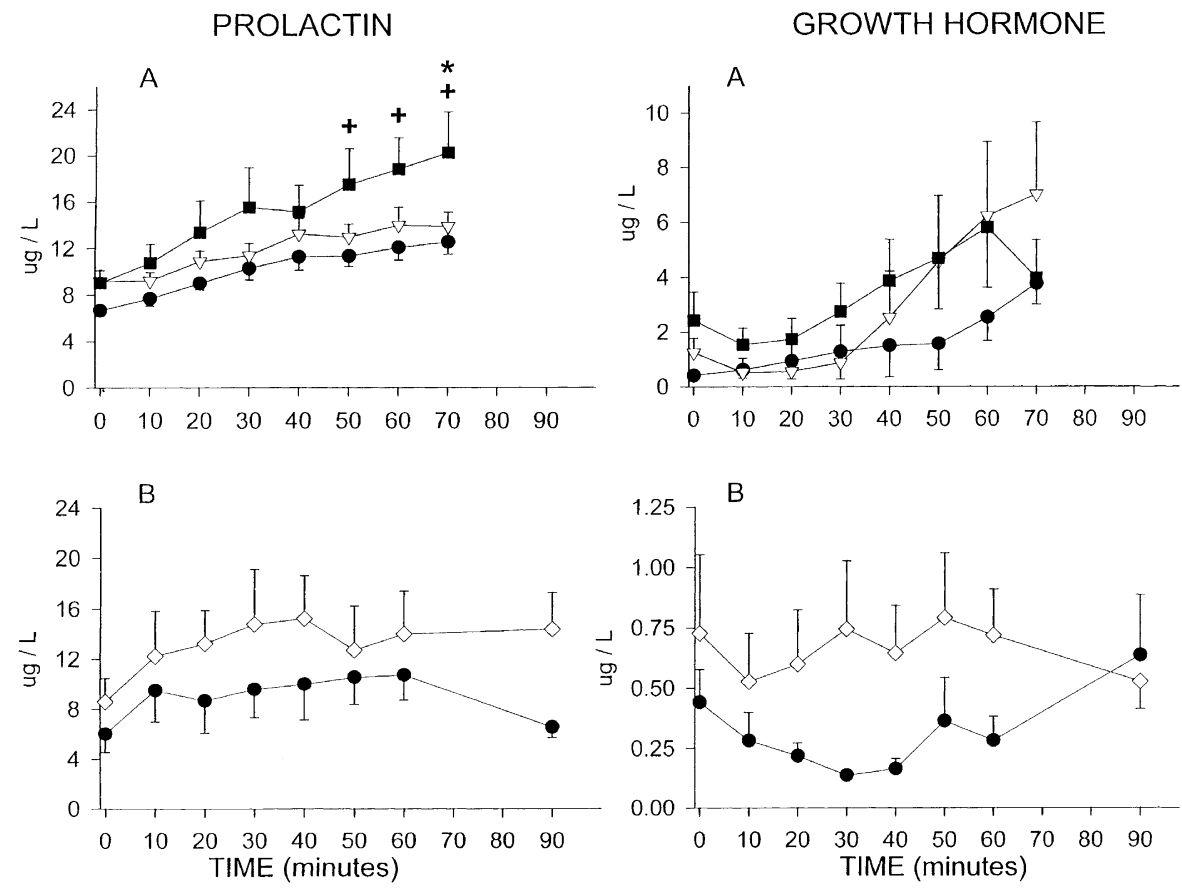

Figure 2. Mean \pm SEM plasma PRL and growth hormone response to m-CPP stimulation during hormonal conditions. A. Women: Basal plasma PRL secretion was significantly higher during both P4 and E2 replacement compared with the hypogonadal state. $\mathrm{m}-\mathrm{CPP}$ stimulated plasma PRL levels were significantly greater during P4 replacement compared with the hypogonadal state at $+50,+60$ and +90 min post $\mathrm{m}-\mathrm{CPP}$ administration (ANOVA-R: hormone condition $\times$ time interaction: $\mathrm{F}_{14,140}=14.8, \mathrm{p}<.001 ; \mathrm{t}_{160}=3.3,3.6$, and 4.1, respectively; $\mathrm{p}<.05$ ). Additionally, $\mathrm{m}-\mathrm{CPP}$ stimulated plasma PRL levels during P4 were significantly greater at the +90 min time point only compared with those observed during the E2 replacement conditions $\left(\mathrm{t}_{160}=3.4 ; \mathrm{p}<.05\right)$.

ANOVA-R showed a significant hormone condition $\times$ time interaction for $\mathrm{GH}\left(\mathrm{F}_{14,140}=2.0, p<.05\right)$, reflecting both a lower basal GH secretion during the hypogonadal condition and a more rapid rise of GH secretion during E2 replacement. However, considerable variation was observed in the m-CPP stimulated GH measures, and no significant differences were observed in integrated measures of GH secretion (i.e. AUC and $\Delta$ max) (Table 2). Basal GH levels during P4 were significantly higher than those during the hypogonadal condition. ( hypogonadal; $\nabla$ E2 replaced; $\mathbf{Q} 4$ replaced) $\left(^{+} \mathrm{P} 4\right.$ replacement vs. hypogonadal state: $p<.05 ;{ }^{*}$ P4 replacement vs. E2 replacement: $p<.05$ )

B. Men: Both basal and m-CPP stimulated plasma PRL secretion was significantly higher during T replacement compared with the hypogonadal state (ANOVA-R: hormone condition: $\mathrm{F}_{1,10}=9.3, p<.05$ ). However, there was no significant hormone condition $\times$ time interaction $\left(\mathrm{F}_{7,70}=1.4, p=\mathrm{NS}\right)$, consistent with the absence of differences in the $\Delta$ max or AUC PRL secretion across hormonal conditions (Table 3 ).

ANOVA-R showed a significant effect of hormone condition $\left(\mathrm{F}_{1,10}=6.3, p<.05\right)$ reflecting higher plasma GH secretion during $\mathrm{T}$ replacement compared with the hypogonadal condition. Basal GH levels were higher but not significantly so during $\mathrm{T}$ replacement, and m-CPP administration failed to significantly increase GH secretion in the men (Table 3). ( hypogonadal; $\diamond \mathrm{T}$ replaced).

Core Temperature and Plasma m-CPP Levels. There were no significant gender differences or time $\times$ gender interactions in measures of core temperature at baseline or after $\mathrm{m}$-CPP stimulation, nor were there gender differences observed in plasma m-CPP levels.

\section{DISCUSSION}

$\mathrm{E} 2$ and P4 in women and T in men increased basal PRL secretion compared with the hypogonadal condition, consistent with the previously reported effects of estrogen replacement in postmenopausal women (Halbreich et al. 1995) and of T replacement in young hypogonadal men (Stoffel-Wagner et al. 1995; Leibenluft et al. 1997). The increased basal secretion of PRL is in keeping with the known abilities of E2 and T (through aromatization to E2) to increase PRL secretion by means of a variety of non-serotonergic mechanisms including increased TRH activity (Lean et al. 1977; Schomburg and Bauer 1997), decreased dopamine D2 receptor activity (Chang et al. 1997; Meller et al. 1992) and direct modulation of PRL gene expression (Maurer et al. 1990). 
Table 3. Basal and m-CPP Stimulated Plasma Hormone Levels in Men during Luproninduced Hypogonadism and after T Replacement (mean $\pm \mathrm{SD}$ ).

\begin{tabular}{lccc}
\hline & Lupron alone & Lupron and T & ANOVA-R $_{\mathbf{1 , 1 0}}(p)$ \\
\hline PRL $(\mu \mathrm{g} / \mathrm{L})$ & & & \\
Basal & $6.0(4.9)$ & $8.6(6.2)$ & $9.3(.01)$ \\
$\Delta$ max & $7.3(5.8)$ & $10.4(9.1)$ & $2.0(\mathrm{NS})$ \\
AUC & $283.8(267.3)$ & $445.8(534.2)$ & $1.5(\mathrm{NS})$ \\
Growth Hormone $(\mu \mathrm{g} / \mathrm{L})$ & & & \\
Basal & $0.4(0.5)$ & $0.7(1.1)$ & $0.8(\mathrm{NS})$ \\
$\Delta$ max & $0.6(0.8)$ & $0.7(0.9)$ & $0.2(\mathrm{NS})$ \\
AUC & $-10.6(34.7)$ & $-6.4(84.6)$ & $0.0(\mathrm{NS})$ \\
ACTH (pmol/L) & & & \\
Basal & $3.8(1.6)$ & $4.9(3.2)$ & $0.6(.1)$ \\
$\Delta$ max & $6.3(3.8)$ & $8.2(11.1)$ & $0.1(\mathrm{NS})$ \\
AUC & $257.1(184.0)$ & $271.8(282.0)$ & $0.2(\mathrm{NS})$ \\
Cortisol (nmol/L) & & & $1.7(\mathrm{NS})$ \\
Basal & $317.3(85.5)$ & $331.1(115.9)$ & $1.5(\mathrm{NS})$ \\
$\Delta$ max & $253.8(104.8)$ & $204.2(118.6)$ & \\
AUC & $13201.8(7556.9)$ & $9777.9(9441.3)$ & \\
\hline
\end{tabular}

Only P4 replacement was associated with a significantly increased PRL secretion after m-CPP administration. In the absence of a pharmacokinetic effect (since plasma $\mathrm{m}-\mathrm{CPP}$ levels were not higher during $\mathrm{P} 4$ re- placement), the observed increase in PRL secretion likely reflects a pharmacodynamic action of P4, or one of its metabolites, altering the activity of the serotonin systems mediating PRL release. Findings in the female
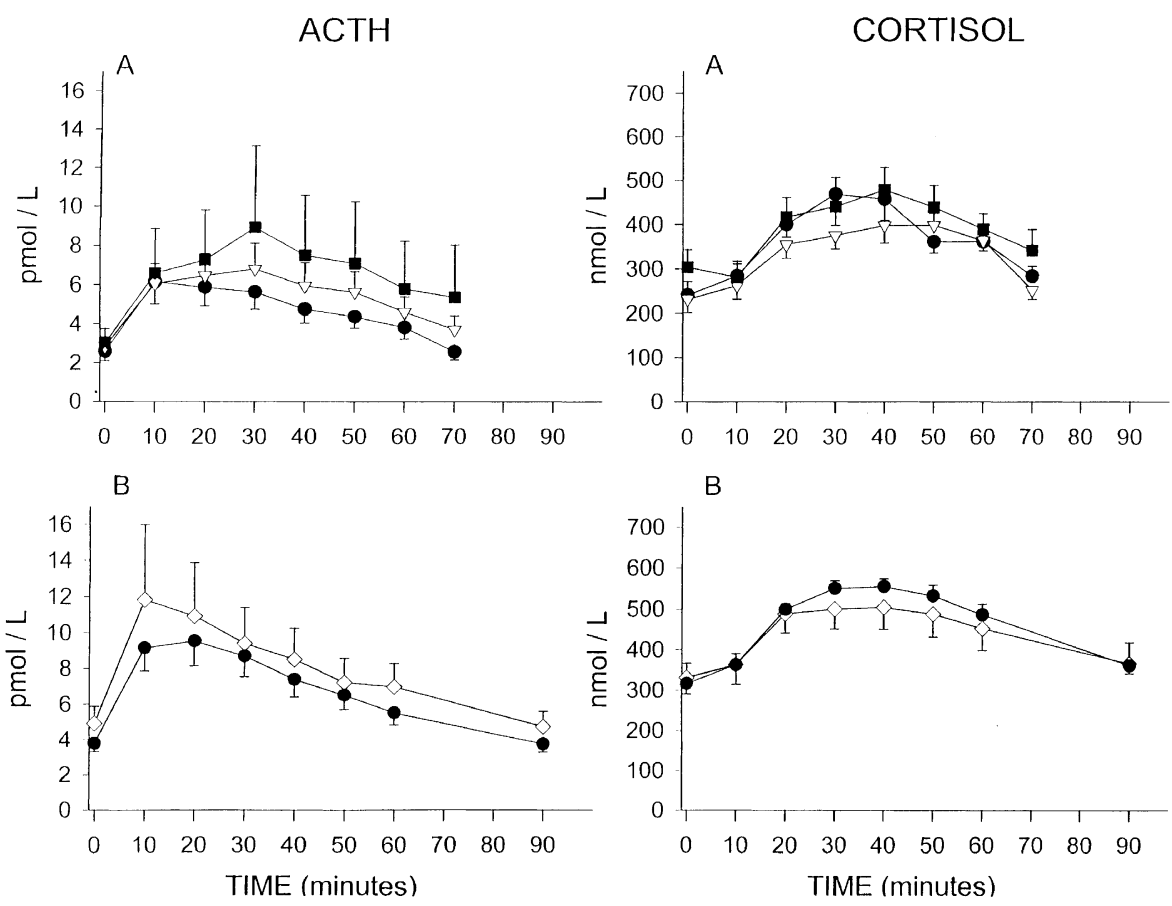

Figure 3. Mean \pm SEM Plasma Levels of m-CPP stimulated ACTH and Cortisol Across Hormonal Conditions.

A. Women: No significant differences in baseline or m-CPP stimulated plasma levels of ACTH or cortisol were observed across the three hormonal conditions (ANOVA-R: hormone condition $\times$ time interaction: $\mathrm{F}_{14,140}=0.9$ and 1.3 , respectively, $p=$ NS). The apparent elevation of plasma levels of ACTH in response to $\mathrm{m}-\mathrm{CPP}$ stimulation during the P4 replacement was due to one of the 11 women having a substantially greater secretion of ACTH during P4 replacement compared with the other hormonal conditions. ( hypogonadal; $\nabla$ E2 replaced; $\mathbf{P} 4$ replaced).

B. Men: No significant differences in baseline or m-CPP stimulated plasma levels of ACTH or cortisol were observed across the two hormonal conditions (ANOVA-R: hormone condition $\times$ time interaction: $\mathrm{F}_{7,70}=0.3$ and 1.6, respectively, $p=\mathrm{NS}$ ). ( hypogonadal; $\diamond \mathrm{T}$ replaced). 

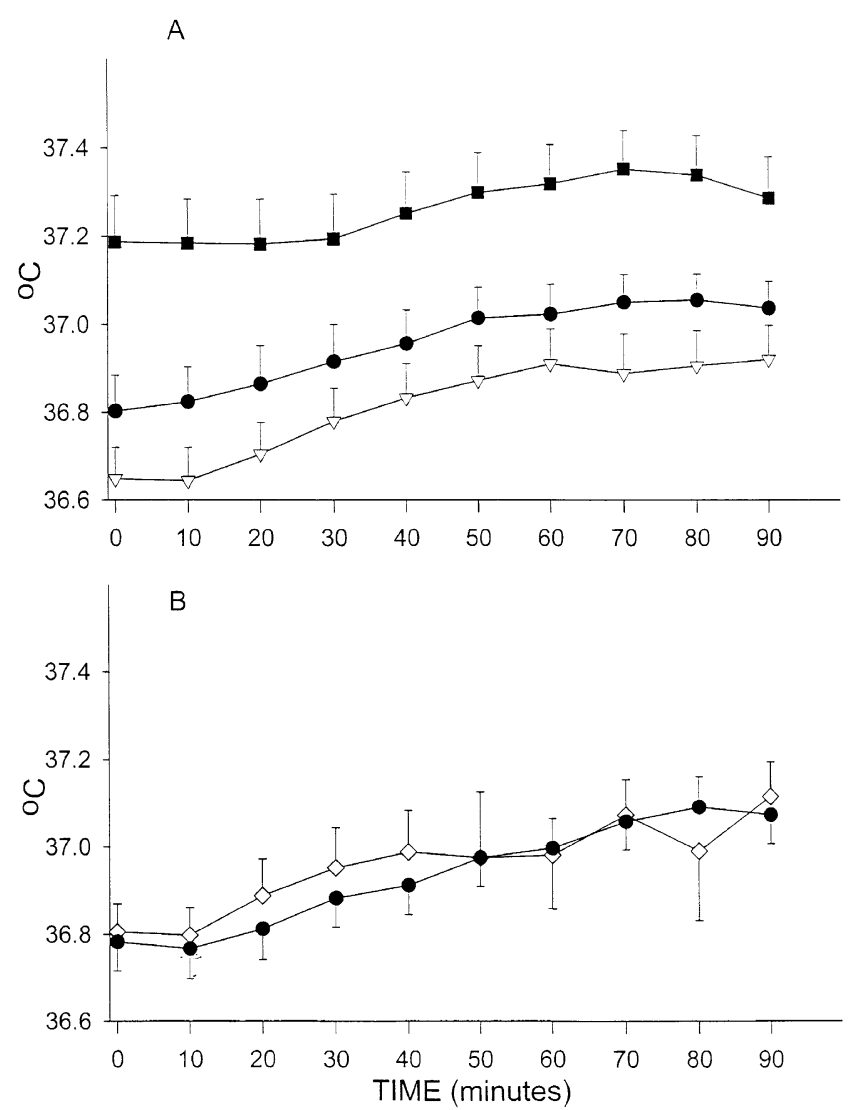

Figure 4. Mean \pm SEM Core Temperature Response to m-CPP Stimulation Across Hormonal Conditions.

A. Women: Core temperature measures were significantly elevated during P4 compared with the hypogonadal condition at the following time points: baseline, $+10,+20,+30$, $+40,+50,+60,+70$, and +90; (ANOVA-R: hormone condition $\times$ time interaction: $\mathrm{F}_{18,162}=2.6, p=.001 ; \mathrm{t}_{180}=4.1-5.5$, $p<.01)$. Core temperature measurements during $\mathrm{P} 4$ replacement were also significantly elevated compared with E2 replacement during all of the time points measured $\left(\mathrm{t}_{180}=\right.$ $5.5-8.3, p<.01)$. No differences between core body temperature measures during the $\mathrm{E} 2$ replacement compared with the hypogonadal condition were observed at any time points $\left(\mathrm{t}_{180}=1.4-2.8 ; p=\mathrm{NS}\right)$. The $\Delta$ max m-CPP-stimulated temperature during $\mathrm{P} 4$ was significantly decreased compared with either E2 replacement or the hypogonadal state, reflecting the elevated basal temperature during $\mathrm{P} 4$ replacement. ( hypogonadal; $\nabla$ E2 replaced; $\mathbf{P} 4$ replaced).

B. Men: ANOVA-R identified no significant effects of hormone condition on the $\mathrm{m}-\mathrm{CPP}$-stimulated temperature $\left(\mathrm{F}_{1,10}=\right.$ $0.1, p=$ NS). ( hypogonadal; $\diamond \mathrm{T}$ replaced $)$.

macaque support a role for an interaction between P4 and the serotonin system in the regulation of PRL secretion and suggest that $\mathrm{P} 4$ acts through the $\mathrm{P} 4$ receptor in the dorsal raphe nucleus to stimulate PRL secretion. Our data in women are consistent with the findings of Bethea $(1993,1994)$ in the macaque except for the requirement of estrogen priming. We observed an increase in PRL secretion in both women receiving P4 af- ter E2 (following the two week washout) as well as those receiving $\mathrm{P} 4$ first with little to no estrogen exposure for the preceding four to six weeks. In fact, the largest PRL secretion observed in this study (as measured by the $\Delta$ max and the AUC) occurred in women randomized to receive $\mathrm{P} 4$ first and not preceded by E2 exposure $(\Delta \max =16.1 \pm 9.7 \mu \mathrm{g} / \mathrm{L}, \mathrm{AUC}=868.3 \pm$ 614) compared with the women receiving $\mathrm{E} 2$ first $(\Delta$ $\max =6.8 \pm 2.2 \mu \mathrm{g} / \mathrm{L}, \mathrm{AUC}=355.2 \pm 188)$. These observations suggest that estrogen induction (estrogen priming) of $\mathrm{P} 4$ receptors is not as necessary in humans as it is in animals (Bethea et al. 1995) or, alternatively, that four to six weeks is not long enough for the downregulation of $\mathrm{P} 4$ receptors to occur after estrogen withdrawal. Alternatively, the enhanced PRL secretion could be secondary to the increased core body temperature observed during $\mathrm{P} 4$ replacement (Brisson et al. 1991); however, no significant correlation existed between the changes from the hypogonadal to P4 replaced conditions in PRL secretion (AUC or $\Delta$ max) and basal temperature. In men, the absence of an enhanced m-CPP stimulated PRL response (i.e. $\Delta$ max or AUC PRL) during $\mathrm{T}$ replacement compared with hypogonadism contrasts with data from Franklin et al. (1996), who reported that castrated rats on a low tryptophan diet had significantly decreased m-CPP stimulated PRL secretion (AUC PRL) compared with both intact and T replaced rats on an identical diet. Employing essentially the same paradigm in humans as that used in rodents, we failed to demonstrate that "castration" or T replacement altered response to serotonergic stimulation.

PRL secretion is dependent on both the dose and plasma level of m-CPP (Murphy et al. 1989; Su et al. 1997). There was no difference, however, between the dose of $\mathrm{m}-\mathrm{CPP}$ or the plasma m-CPP levels during P4 replacement compared with the hypogonadal state. Indeed, the only differences in dose and plasma levels (within the first six minutes after administration) were observed during the E2 and T replacement conditions and did not result in increased levels of hormone secretion relative to those seen in the other conditions. Nonetheless, it is possible that additional effects of gonadal steroids on serotonergic function would be revealed were a range of levels of either $\mathrm{m}-\mathrm{CPP}$ or hormone replacement used to characterize what may be complex dose response curves.

The increase in m-CPP stimulated PRL secretion during $\mathrm{P} 4$ replacement but not E2 replacement in women or $\mathrm{T}$ replacement in men is surprising and contrary to the observations in animals of alterations in many measures of 5-HT system function in association with estrogen administration (Rubinow et al. 1998). Our data could suggest the following: (1) m-CPP stimulated PRL secretion is not occurring by means of a serotonergic mechanism (Hamik and Peroutka 1989); (2) the components of the serotonergic system involved in PRL 
Table 4. Basal and m-CPP Stimulated Plasma Hormone Levels during Lupron-induced Hypogonadism in Women and Men (mean \pm SD).

\begin{tabular}{lccc}
\hline & Women $(\mathbf{n}=\mathbf{1 1})$ & Men $(\mathbf{n}=\mathbf{1 1})$ & ${\text { ANOVA-R } \mathbf{F}_{\mathbf{1 , 2 0}}(\boldsymbol{p})}$ \\
\hline PRL $(\mu \mathrm{g} / \mathrm{L})$ & & & \\
Basal & $6.7(1.6)$ & $6.0(4.9)$ & $0.2(\mathrm{NS})$ \\
$\Delta$ max & $6.7(3.2)$ & $7.3(5.8)$ & $0.1(\mathrm{NS})$ \\
AUC & $359.3(201.6)$ & $283.8(267.3)$ & $0.6(\mathrm{NS})$ \\
Growth Hormone $(\mu \mathrm{g} / \mathrm{L})$ & & & \\
Basal & $0.4(0.6)$ & $0.4(0.5)$ & $0.0(\mathrm{NS})$ \\
$\Delta$ max & $4.3(3.3)$ & $0.6(0.8)$ & $13.8(.001)$ \\
AUC & $131.2(159.3)$ & $-10.6(34.7)$ & $8.3(.01)$ \\
ACTH $(\mathrm{pmol} / \mathrm{L})$ & & & \\
Basal & $2.6(1.6)$ & $3.8(1.6)$ & $2.1(.09)$ \\
$\Delta$ max & $4.1(2.8)$ & $6.3(3.8)$ & $2.0(\mathrm{NS})$ \\
AUC & $161.8(127.3)$ & $257.1(184.0)$ & $3.5(.08)$ \\
Cortisol $(\mathrm{nmol} / \mathrm{L})$ & & & $0.0(\mathrm{NS})$ \\
Basal & $242.8(99.3)$ & $317.3(85.5)$ & $0.6(\mathrm{NS})$ \\
$\Delta$ max & $245.6(154.5)$ & $253.8(104.8)$ & \\
AUC & $10611.1(8635.7)$ & $13201.8(7556.9)$ & \\
\hline
\end{tabular}

secretion are not modulated by $\mathrm{E} 2$ or $\mathrm{T}$, but are by $\mathrm{P} 4$; or (3) the stimulatory effects of $\mathrm{m}-\mathrm{CPP}$ and $\mathrm{P} 4$ are additive but independent. Pharmacologic studies employing serotonin receptor antagonists have suggested that in humans $\mathrm{m}-\mathrm{CPP}$ stimulated PRL release is mediated by an increase in 5- $\mathrm{HT}_{2 \mathrm{C}}$ activity (Yasui et al. 1995). However, selective and specific serotonin receptor antagonists are not available currently and, therefore, the exact serotonin receptor(s) involved in the m-CPP stimulated PRL release is a matter of speculation (Murphy et al. 1995). E2 has been shown to modulate brain serotonin (Biegon et al. 1983) and serotonin transporter (McQueen et al. 1996; Pecins-Thompson et al. 1998) levels and the activity of both 5- $\mathrm{HT}_{1 \mathrm{~A}}$ (Clarke and Maayani 1990; Thomas et al. 1997) and 5- $\mathrm{HT}_{2 \mathrm{~A}}$ (Sumner and Fink 1995; Sumner and Fink 1993) receptors in animals, but the role of $\mathrm{E} 2$ or $\mathrm{T}$ in modulation of the $5-\mathrm{HT}_{2 \mathrm{C}}$ receptor is largely unknown. Similarly, the effects of P4 on this receptor subsystem have not been reported. The lower basal GH secretion during GnRH-agonist induced hypogonadism compared with both $\mathrm{P} 4$ and, albeit nonsignificantly, E2 replacement in women (Table 2) and to $\mathrm{T}$ replacement in men (Table 3 ) is consistent with previous studies suggesting the GH stimulating effects of gonadal steroids, particularly E2, in both women and men (Giustina and Veldhuis 1998; Wiedemann et al. 1998; Kooistra et al. 1998; Rijnberk and Mol 1997). We also observed a significant increase in GH secretion after $\mathrm{m}$-CPP stimulation in the women but not in men. These data reflect not only the failure of $\mathrm{m}-\mathrm{CPP}$ to consistently stimulate GH secretion in the men but also an enhanced $\mathrm{GH}$ secretion in the women during the latter part of the $\mathrm{m}$-CPP challenge. The latency of $\mathrm{GH}$ response to $\mathrm{m}-\mathrm{CPP}$ administration in women suggests that the ultradian secretion of GH may be responsible for the enhanced GH secretion that we observed rather than any direct effects of m-CPP stimulation. In fact, previous studies (Giustina and Veldhuis 1998) have described that women have a significantly greater amplitude of GH secretion compared with men. Our data would suggest that the sexual dimorphism in the amplitude of GH secretion occurs independent of the presence of the activating effects of gonadal steroids (i.e. it was present during induced hypogonadism) and may, therefore, represent organizational effects of gonadal steroids occurring earlier in development.

Our failure to observe significant gonadal steroidrelated differences in hypothalamic-pituitary-adrenal (HPA) axis function in women or men contrasts with the considerable literature in animals and with the more modest literature in humans suggesting a prominent role of gonadal steroids in HPA axis regulation (Roca et al. 1999). We did note a trend for basal cortisol levels to be increased during P4 administration, consistent with the independent observation of significantly increased cortisol response to exercise (treadmill stress) during P4 (but not E2) relative to Lupron-induced hypogonadism (Roca et al. 1998). Additionally, we did identify significant gender-related differences in $\mathrm{m}-\mathrm{CPP}-$ stimulated ACTH and cortisol secretion, with men observed to have increased levels when all time points were analyzed (ANOVA-R) in the total sample, as well as increased AUC, $\Delta$ max, and max in the subgroup matched for baseline plasma $\mathrm{T}$ levels. These observed gender differences in HPA axis activity during hypogonadism are similar to reports by Roca et al. (2000) employing the exercise challenge. As with the mechanism of $\mathrm{m}$-CPP-stimulated PRL secretion, the regulatory systems mediating m-CPP stimulation of the HPA axis have not been clearly identified. Thus, it is possible that 
gonadal steroids have little role in the regulation of $\mathrm{m}$-CPP stimulated cortisol or ACTH secretion, but may, in fact, influence HPA response to other stimuli. Alternatively, the effects of gonadal steroids, at least estradiol, in humans may be less robust than those observed in animals, or may not be apparent with the steady state hormone levels used in this study. As a caveat, the duration of induced hypogonadism as well as the duration of gonadal steroid replacement are both relatively brief and fixed. Thus, our paradigm does not comprehensively model either physiologic gonadal function or hypogonadism (secondary to either reproductive senescence or surgery).

The increase in core temperature observed during P4 replacement conditions is consistent with previous reports of P4-induced thermogenesis. Our observation is also paralleled by our earlier demonstration of an elevated baseline and lower $\Delta$ max core temperature after oral $\mathrm{m}$-CPP administration in women during the luteal phase ( $\mathrm{Su}$ et al. 1994), a time of increased P4 secretion, albeit in the presence of E2. Additionally, our data and that of previous studies (Prior et al. 1995; Israel and Schneller 1950) suggest that $P 4$ 's effects on core temperature can occur independent of recent prior estrogen exposure and, therefore, absent estrogen's action on the $\mathrm{P} 4$ receptor.

Irrespective of the mechanisms of action of $\mathrm{m}-\mathrm{CPP}$, our findings represent the first study in humans to examine, under controlled conditions, the effects of individual gonadal steroids on the serotonergic system. Our data suggest that several of the menstrual cycle phase effects of putative serotonergic agonists on PRL secretion may be as much related to the effects of P4 during the luteal phase as they are related to estrogen secretion. Additionally, in contrast to the animal literature, our findings in humans document that some of the effects of P4 may occur absent estrogen's induction of the P4 receptor. Similarly, we could not confirm in humans the observations in animals (Fischette et al. 1984; Franklin et al. 1996) that $\mathrm{T}$ influences the physiologic response to serotonergic stimulation. Although our data was adequately powered to demonstrate a number of significant effects of gonadal steroids on serotonergic measures, the possibility of a Type II error cannot be ruled out for those measures in which no effects of gonadal steroid condition were observed. Finally, our data demonstrate that in humans, as in animals, some sexual dimorphisms in hormonal regulation occur independent of the presence of gonadal steroids.

\section{ACKNOWLEDGMENTS}

We wish to acknowledge the helpful comments of David R. Rubinow, M.D. in the execution of the study and the preparation of the manuscript.

\section{REFERENCES}

Abraham GE, Swerdloff R, Tulchinsky D, Odell WD (1971): Radioimmunoassay of plasma progesterone. J Clin Endocrinol Metab 32:619-624

Anand A, Charney DS, Delgado PL, McDougle CJ, Heninger GR, Price LH (1994): Neuroendocrine and behavioral responses to intravenous $m$-Chlorophenylpiperazine $(\mathrm{mCPP})$ in depressed patients and healthy comparison subjects. Am J Psychiatry 151:1626-1630

Anderson IM, Parry-Billings M, Newsholme EA, Fairburn CG, Cowen PJ (1990): Dieting reduces plasma tryptophan and alters brain 5-HT function in women. Psychol Med 20:785-791

Aubert ML, Becker RL, Saxena BB, Raiti S (1974): Report of the National Pituitary Agency. Collaborative study of the radioimmunoassay of human prolactin. J Clin Endocrinol Metab 38:1115-1120

Bethea CL (1993): Colocalization of progestin receptors with serotonin in raphe neurons of macaque. Neuroendocrinology 57:1-6

Bethea CL (1994): Regulation of progestin receptors in raphe neurons of steroid-treated monkeys. Neuroendocrinology 60:50-61

Bethea CL, Hess DL, Widmann AA, Henningfeld JM (1995): Effects of progesterone on prolactin, hypothalamic $\beta$-endorphin, hypothalamic substance $P$, and midbrain serotonin in guinea pigs. Neuroendocrinology 61:695-703

Biegon A, Reches A, Snyder L, McEwen BS (1983): Serotonergic and noradrenergic receptors in the rat brain: modulation by chronic exposure to ovarian hormones. Life Sci 32:2015-2021

Biver F, Lotstra F, Monclus M, Wikler D, Damhaut P, Mendlewicz J, Goldman S (1996): Sex difference in $5 \mathrm{HT}_{2}$ receptor in the living human brain. Neurosci Lett 204: 25-28

Brisson GR, Peronnet F, Perrault H, Boisvert P, Massicotte D, Gareau R (1991): Prolactinotrophic effect of endogenous and exogenous heat loads in human male adults. J Appl Physiol 70:1351-1355

Chang A, Shin SH, Pang SC (1997): Dopamine D2 receptor mediates both inhibitory and stimulatory actions on prolactin release. Endocrine 7:177-182

Charney DS, Woods SW, Goodman WK, Heninger GR (1987): Serotonin function in anxiety: II. Effects of the serotonin agonist MCPP in panic disorder patients and healthy subjects. Psychopharmacology (Berl) 92:14-24

Chrousos GP, Schulte HM, Oldfield EH, Gold PW, Cutler GW, Loriaux DL (1984): Corticotropin stimulation test: an aid in the evaluation of patients with Cushing's Syndrome. N Engl J Med 310:622-627

Clarke WP, Maayani S (1990): Estrogen effects on 5- $\mathrm{HT}_{1 \mathrm{~A}}$ receptors in hippocampal membranes from ovariectomized rats: functional and binding studies. Brain Res 518:287-291

Ellenbogen MA, Young SN, Dean P, Palmour RM, Benkelfat C (1996): Mood response to acute tryptophan depletion in healthy volunteers: sex differences and temporal stability. Neuropsychopharmacology 15:465-474

Fink G, Sumner BEH, Rosie R, Grace O, Quinn JP (1996): 
Estrogen control of central neurotransmission: effect on mood, mental state, and memory. Cell Mol Neurobiol 16:325-344

Fischette CT, Biegon A, McEwen BS (1984): Sex steroid modulation of the serotonin behavioral syndrome. Life Sci 35:1197-1206

Franklin M, Craven RD, Cowen PJ (1996): Effect of castration and castration with hormone replacement on the plasma prolactin responses to neuroendocrine challenge with i.v. $\mathrm{mCPP}$ in the male rat following a low tryptophan diet. J Psychopharmacol 10:250-253

Furuyama S, Mayes DM, Nugent CA (1970): A radioimmunoassay for plasma testosterone. Steroids 16:415-428

Giustina A, Veldhuis JD (1998): Pathophysiology of the neuroregulation of growth hormone secretion in experimental animals and the human. Endocr Rev 19:717-797

Goodwin GM, Murray CL, Bancroft J (1994): Oral d-fenfluramine and neuroendocrine challenge: problems with the $30 \mathrm{mg}$ dose in men. J Affect Disord 30:117-122

Guicheney P, Léger D, Barrat J, Trévoux R, De Ligniéres B, Roques P, Garnier JP, Boyer P, Grenier J, Dreux C, Meyer P (1988): Platelet serotonin content and plasma tryptophan in peri- and postmenopausal women: variations with plasma oestrogen levels and depressive symptoms. Eur J Clin Invest 18:297-304

Halbreich U, Rojansky N, Palter S, Tworek H, Hissin P, Wang K (1995): Estrogen augments serotonergic activity in postmenopausal women. Biol Psychiatry 37:434-441

Hamik A, Peroutka SJ (1989): 1-(m-chlorophenyl)piperazine $(\mathrm{mCPP})$ interactions with neurotransmitter receptors in the human brain. Biol Psychiatry 25:569-575

Israel SL, Schneller O (1950): The thermogenic property of progesterone. Fertil Steril 1:53-65

Jiang N-S, Ryan PJ (1969): Radioimmunoassay for estrogens: a preliminary communication. Mayo Clin Proc 44: 461-465

Klemm W, Gupta D (1975): A routine method for the radioimmunoassay of plasma cortisol without chromatography. In Gupta D (ed), Radioimmunoassay of Steroid Hormones. Weinheim, Verlag Chemie, pp 143-151

Kooistra HS, Voorhout G, Selman PJ, Rijnberk A (1998): Progestin-induced growth hormone $(\mathrm{GH})$ production in the treatment of dogs with congenital GH deficiency. Domest Anim Endocrinol 15:93-102

Kornstein SG, Schatzberg AF, Thase ME, Yonkers KA, McCullough JP, Keitner GI, Gelenberg AJ, Davis SM, Harrison WM, Keller MB (2000): Gender differences in treatment response to sertraline versus imipramine in chronic depression. Am J Psychiatry 157:1445-1452

Lean AD, Garon M, Kelly PA, Labrie F (1977): Changes of pituitary thyrotropin releasing hormone $(\mathrm{TRH})$ receptor level and prolactin response to TRH during the rat estrous cycle. Endocrinology 100:1505-1510

Leibenluft E, Schmidt PJ, Turner EH, Danaceau MA, Ashman SB, Wehr TA, Rubinow DR (1997): Effects of leuprolide-induced hypogonadism and testosterone replacement on sleep, melatonin, and prolactin secretion in men. J Clin Endocrinol Metab 82:3203-3207

Lepage P, Steiner M (1991): Gender and serotonergic dysregulation: implications for late luteal phase dysphoric disorder. In Cassano GB, Akiskal HS (eds), Serotoninrelated Psychiatric Syndromes: Clinical and Therapeutic Links. Ontario, Canada, Royal Society of Medicine Services Limited, pp 131-143

Lippert TH, Filshie M, Mück AO, Seeger H, Zwirner M (1996): Serotonin metabolite excretion after postmenopausal estradiol therapy. Maturitas 24:37-41

Maurer RA, Kim KE, Day RN, Notides AC (1990): Regulation of prolactin gene expression by estradiol. Prog Clin Biol Res 322:159-169

McQueen JK, Wilson H, Fink G (1997): Estradiol-17ß increases serotonin transporter (SERT) mRNA levels and the density of SERT-binding sites in female rat brain. Mol Brain Res 45:13-23

Meller E, Puza T, Diamond J, Lieu HD, Bohmaker K (1992): Comparative effects of receptor inactivation, 17 betaestradiol and pertussis toxin on dopaminergic inhibition of prolactin secretion in vitro. J Pharmacol Exp Ther 263:462-469

Murphy DL, Aulakh C, Mazzola-Pomietto P, Briggs NC (1995): Neuroendocrine responses to serotonergic agonists as indices of the functional status of central serotonin neurotransmission in humans: a preliminary comparative analysis of neuroendocrine endpoints versus other endpoint measures. Behav Brain Res 73:209-214

Murphy DL, Mueller EW, Hill JL, Tolliver TJ, Jacobsen FM (1989): Comparative anxiogenic, neuroendocrine, and other physiologic effects of $m$-chlorophenylpiperazine given intravenously or orally to healthy volunteers. Psychopharmacology (Berl) 98:275-282

Nishizawa S, Benkelfat C, Young SN, Leyton M, Mzengeza S, de Montigny C, Blier P, Diksic M (1997): Differences between males and females in rates of serotonin synthesis in human brain. Proc Natl Acad Sci USA 94: $5308-5313$

O'Keane V, O'Hanlon M, Webb M, Dinan T (1991): d-Fenfluramine/prolactin response throughout the menstrual cycle: evidence for an oestrogen-induced alteration. Clin Endocrinol 34:289-292

Odell WD, Rayford PL, Ross GT (1967): Simple partially automated method for radioimmunoassay of human thyroid stimulating, growth, luteinizing and follicle stimulating hormone. J Lab Clin Med 70:973-980

Pecins-Thompson M, Brown NA, Bethea CL (1998): Regulation of serotonin re-uptake transporter mRNA expression by ovarian steroids in rhesus macaques. Brain Res Mol Brain Res 53:120-129

Prior JC, McKay DW, Vigna YM, Barr SI (1995): Medroxyprogesterone increases basal temperature: a placebocontrolled crossover trial in postmenopausal women. Fertil Steril 63:1222-1226

Rijnberk A, Mol JA (1997): Progestin-induced hypersecretion of growth hormone: an introductory review. J Reprod Fertil (Suppl 51):335-338

Roca CA, Altemus M, Schmidt PJ, Deuster P, Gold P, Rubinow DR (1998): Effect of gonadal steroids on hypothalamic-pituitary adrenal (HPA) axis function. Abstracts of 80 th \& 82nd Annual Meeting of the Endocrine Society, p 337

Roca CA, Schmidt PJ, Altemus MA, Deuster P, Gold PW, Rubinow DR (2000): Gender differences and the effect 
of gonadal steroids on the hypothalamic-pituitaryadrenal (HPA) axis response to stress. Abstracts of 80th \& 82nd Annual Meeting of the Endocrine Society, p 459

Roca CA, Schmidt PJ, Rubinow DR (1999): Gonadal steroids and affective illness. Neuroscientist 5:227-237

Rubinow DR, Schmidt PJ, Roca CA (1998): Estrogen-serotonin interactions: implications for affective regulation. Biol Psychiatry 44:839-850

Schneider LS, Small GW, Hamilton SH, Bystritsky A, Nemeroff CB, Meyers BS (1997): Estrogen replacement and response to fluoxetine in a multicenter geriatric depression trial. Am J Geriatr Psychiatry 5:97-106

Schomburg L, Bauer K (1997): Regulation of the adenohypophyseal thyrotropin-releasing hormone-degrading ectoenzyme by estradiol. Endocrinology 138:3587-3593

Sherwin BB, Suranyi-Cadotte BE (1990): Up-regulatory effect of estrogen on platelet $3 \mathrm{H}$-imipramine binding sites in surgically menopausal women. Biol Psychiatry 28:339-348

Spitzer RL, Williams JB, Gibbon M, First MB (1990): Structured clinical interview for DSM-III-R, patient edition. New York, NY, Biometrics Research Department, New York State Psychiatric Institute

Stoffel-Wagner B, Sommer L, Bidlingmaier F, Klingmuller D (1995): Effects of the gonadotropin-releasing-hormone agonist, D-Trp-6-GnRH, on prolactin secretion in healthy young men. Horm Res 43:266-272

Su T-P, Danaceau MA, Schmidt PJ, Rubinow DR (1994): Effect of menstrual cycle phase on biochemical and behavioral response to m-CPP. Biol Psychiatry 35:661
Su T-P, Schmidt PJ, Danaceau M, Murphy DL, Rubinow DR (1997): Effect of menstrual cycle phase on neuroendocrine and behavioral responses to the serotonin agonist $\mathrm{m}$-chlorophenylpiperazine in women with premenstrual syndrome and controls. J Clin Endocrinol Metab $82: 1220-1228$

Sumner BEH, Fink G (1993): Effects of acute estradiol on 5-hydroxytryptamine and dopamine receptor subtype mRNA expression in female rat brain. Mol Cell Neurosci 4:83-92

Sumner BEH, Fink G (1995): Estrogen increases the density of 5-hydroxytryptamine ${ }_{2 \mathrm{~A}}$ receptors in cerebral cortex and nucleus accumbens in the female rat. J Steroid Biochem Molec Biol 54:15-20

Thomas ML, Bland DA, Clarke CH, Cunningham KA (1997): Estrogen regulation of serotonin (5-HT) transporter and $5-\mathrm{HT}_{1 \mathrm{~A}}$ receptor mRNA in female rat brain. Abstr Soc Neurosci 23:1501

Vermeulen A, Stoica T, Verdonck L (1971): The apparent free testosterone concentration, an index of androgenicity. J Clin Endocr 33:759-767

Wiedemann K, Lauer CJ, Hirschmann M, Knaudt K, Holsboer F (1998): Sleep-endocrine effects of mifepristone and megestrol acetate in healthy men. Am J Physiol 274:E139-E145

Yasui N, Otani K, Kaneko S, Ohkubo T, Osanai T, Ishida M, Mihara K, Kondo T, Sugawara K, Fukushima Y (1995): Inhibition of trazodone metabolism by thioridazine in humans. Ther Drug Monit 17:333-335

Yatham LN, Barry S, Dinan RG (1989): Serotonin receptors, buspirone, and premenstrual syndrome. Lancet 1 : $1447-1448$ 